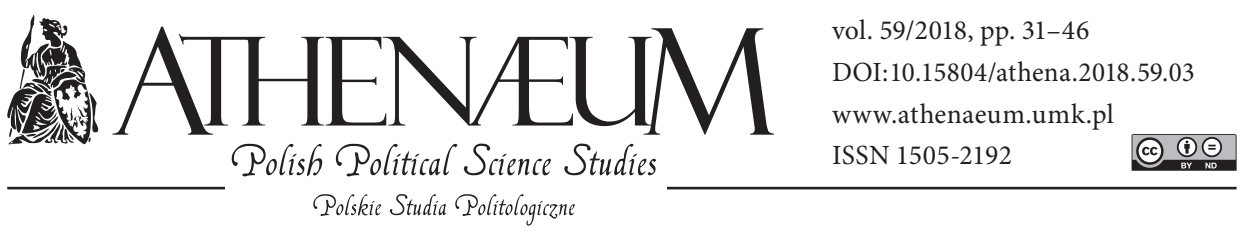

\title{
STATEHOOD WITHOUT THE STATE: THE POLITICO-LEGAL VISIONS OF THE FUTURE STATE OF TIBET
}

\author{
PAŃSTWOWOŚĆ BEZ PAŃSTWA. \\ WIZJE POLITYCZNO-PRAWNE PRZYSZŁEGO PAŃSTWA TYBET
}

Marcin Lisiecki*$$
\text { ABSTRACT }
$$

The main purpose of this article is to analyze the situation of modern Tibet, which political and legal structures are divided into the Central Tibetan Administration in India and the Tibet Autonomous Region in China. What connects them is a developing national identity of the Tibetans and the actions taken by the Central Tibetan Administration to create a new and independent state. Of great importance for the specificity of politics and the shaping of Tibetan national identity are also activities of the $14^{\text {th }}$ Dalai Lama, who internationally promotes Tibetan culture and informs about the situation of Tibetans living in the Tibet Autonomous Region in China.

Dalai Lama is also the author of the draft constitution of the future state of Tibet, which content is a basis of the analysis in this article. Due to the comprehensive presentation and explanation of the specifics of this project, we will analyze not only particular articles, but also the
\end{abstract}

Głównym celem niniejszego artykułu jest analiza sytuacji współczesnego Tybetu, którego struktury polityczne i prawne podzielone są na Centralny Rząd Tybetański w Indiach i Tybetański Region Autonomiczny w Chinach. Tym, co je łączy, są kształtująca się tożsamość narodowa Tybetańczyków oraz działania podejmowane przez Centralny Rząd Tybetański na rzecz stworzenia nowego i niepodległego państwa. Duże znaczenie dla specyfiki polityki i kształtowania tybetańskiej tożsamości narodowej ma również działalność XIV Dalajlamy, który na arenie międzynarodowej promuje kulturę tybetańską oraz informuje o sytuacji Tybetańczyków żyjących w Tybetańskim Regionie Autonomicznym w Chinach.

Dalajlama jest również autorem projektu konstytucji przyszłego państwa Tybet, której treść stanowi podstawę analizy zawartej w niniejszym artykule. Ze względu na kompleksowe ukazanie i wyjaśnienie specyfiki tego projektu zajmiemy się analizą nie tylko poszczególnych

* Nicolaus Copernicus University in Toruń, Faculty of Political Sciences and International Studies. ORCID: https://orcid.org/0000-0001-6531-616X. 
introduction that we can consider as preamble. Thanks to this, it will be possible to show the relationship between political, legal and religious issues that make up the visions of the new state of Tibet.

This article is divided into two related parts. The first one is connected with national identity and independence of Tibet. The second part is focused on democratization of Tibet and relation between religion and politics.

Keywords: Tibet, Tibetans, China, Dalai Lama, national identity, independence, constitution, Buddhism artykułów, lecz także wprowadzenia, które uznać możemy za preambułę. Dzięki temu możliwe będzie wykazanie związków między kwestiami politycznymi, prawnymi a religijnymi, składającymi się na wizję nowego państwa Tybet. $\mathrm{Z}$ tego też powodu artykuł podzielony jest na dwie powiązane ze sobą części. Pierwsza dotyczy tożsamości narodowej i niepodległości Tybetu, zaś druga demokratyzacji Tybetu i związków między religią a polityką.

Słowa kluczowe: Tybet, Tybetańczycy, Chiny, Dalajlama, tożsamość narodowa, niepodległość, konstytucja, buddyzm

Although it is difficult to predict the future

All human beings who wish to achieve happiness

And avoid suffering

Must plan for the future.

Dalai Lama, The Politics of Future Tibet

What is so telling about the publications on Tibet (Tib. bod) which has been recently released in the West is the fact that the forewords to many of them were written by the $14^{\text {th }}$ Dalai Lama (Tib. taa-la'ibla-ma). There are three reasons for which the attention should be paid to them as well as to (and perhaps mainly so) to their author. First of all, Dalai Lama is - not only among the adherents of Tibetan Buddhism - an exceptionally significant and respectable person in the contemporary world (cf. Powers, 2007, pp. 213-214). Second of all, due to these forewords, he promoted Tibetan culture and turned our attention to the issues related to Tibet as well as the current situation of Tibetans (cf. Mullin, 2008, pp. 535-538). This reason is nowadays noticed and included in the discussion over human-rights-related issues within the context of persecuting Tibetan people in China. However, it is not only these particular reasons for which it is important because - and it is a third reason - Dalai Lama is not only the most significant priest in Gelug school (Tib. dge lugs pa) of Tibetan Buddhism but also a political leader of Tibetans. It is worthwhile to take heed of the latter because it is reflected in the foreword written by Dalai Lama to the book by 
Glenn H. Mullin bearing the title The Fourteen Dalai Lamas: A Sacred Legacy of Reincarnation. He wrote that in recent years what became evident is the growing interest in Tibet and its rich ancient culture as well as in the lineage of Dalai Lamas as an institution (2008, p. 13). We should construe this utterance as implying that Tibet-related issues may be considered multi-dimensionally because they relate both to literature, language, religion, as well as to the issues pertaining to politics.

The contemporary studies related to politics of Tibet are to a large extent devoted to the issues pertinent to history and international relations, mainly including conflicts with China. On the other hand, to a much lesser degree, they are related to its internal policies. It should be underlined that these policies are quite idiosyncratic because they are connected with two mutually independent political structures. First of them is, operating in Dharamshala in India, Tibetan government in exile, that is the Central Tibetan Administration (Tib. bod mi'isgrig 'dzugs, CTA). The other one is the Tibet Autonomous Region (Chin. Xìzàngzizhiqū, Tib. bod rang skyongljongs, TAR) located in Tibet but being subordinated to the state structures of the People's Republic of China (Chin. ZhōnghuáRénminGònghéguó). What is of special interest is the fact that the Central Tibetan Administration, which is endowed with the parliament being referred to as Kashag (Tib. bka'-shag), with Prime Ministry, seven Departments (Religion and Culture, Home, Finance, Education, Security, Information and International Relations, Health), party system (including two main parties: National Democratic Party of Tibet, People's Party of Tibet) and legal parliamentary elections to Kashag. The enumeration should also include the draft of the constitution, which exemplifies an interesting process of pursuing and shaping a polity in the case of a political structure deprived of the state territory. What is meant thereby is a draft of the constitution of future Tibet known as Constitution of Tibet (Tib. bod kyartsakhrims) of 10 March 1963'.

Undertaking the analysis of Tibetan policies stems mainly from that fact that contemporary Tibet constitutes a very interesting case from a legal standpoint. To this day, Tibet has not lost its statehood, is an independent state under illegal

1 It must be underlined that despite the title suggestion of an official and binding document, we deal here only with a draft. In the present paper, the content of a draft of the Tibetan constitution of 1963 will be supplemented with the threads derived from a slightly amended text of this constitution as of 1992. Apart from a few threads that will be touched up later on, the amendments mainly relate to the extension of the introduction. 
occupation (van Walt van Praag, 1988). It means that in the first place, we should pay attention to the fact that the policies pursued by contemporary Tibet are related to - apparently independent of one another - CTA and also TAR. And in principle, if we are to understand their idiosyncrasies, we should combine one with the other. The situation will become clearer when we take heed of the genesis and the content of The Constitution of Tibet (1963) because it contains the propositions related to the polity of the future state of Tibet. It must be added that the suggestions as to a political and legal regime were mainly prepared by Dalai Lama and in the majority of cases, the said propositions reach the public opinion (Tibetan and the international one) and they shape the consciousness of Tibet- and Tibetans-related issues. We can point to five significant threads in the content of this proposition, the threads being related to the policies of the future state of Tibet. These are, in order:

- independence of Tibet;

- national identity of Tibetan people;

- democratisation of Tibetan political system;

- religion and culture;

- position of Dalai Lama.

In the present paper, we shall pay special attention to the text of a draft of the constitution - both to the introduction thereto, which can be regarded as a preamble, and to particular articles. The successive part of the article, in the light of the points made above, shall be divided into two sub-sections, being related to national identity and independence, as well as religion and a polity of future Tibet.

\section{INDEPENDENCE OF TIBET AND NATIONAL IDENTITY}

The choice of the theme of Tibet having regained its independence as the first section stems from the content of a draft of the constitution. Its significance may lie in the fact that the said independence is constitutive of other actions aimed at shaping new politico-legal regime in Tibet. It must be added that independence is construed here as Tibet's political - and only implicitly: cultural and economic one - independence of China. What is symptomatic of such texts, as well as to nation-forming processes, is the fact that these issues are presented in astoundingly generic terms. Also in the case of Tibetan project, apart from a few remarks in the preamble stating that Tibet is a colony of China as well as the use of such 
expressions as "freedom" and "independence" 2 , there is no further information on how independence should be construed. This information may be found in the introduction appended to a draft of the constitution of 1992, which does not perform the role of a preamble but rather that of guidelines on the situation of Tibet while being definitely directed to the Western reader - rather than to indigenous Tibetans. We can read therein what follows: "As a result of the Chinese occupation, Tibetans in Tibet are deprived of their basic human rights; this tragic situation cannot be permitted to continue for long. [...] However, by the middle of this century, Chinese occupation forces marched into Tibet through its eastern border regions of Kham and Amdo. Soon after, the Chinese intensified their military repression in Tibet, driving our political situation to a crisis point. [...] In the hope of winning peace and happiness for my people, I tried for years to establish an amicable relationship with the powerful and authoritarian Chinese officials [...]. As soon as the Chinese army had gained full control of Tibet, they shed their initial semblance of discipline and politeness to become ever more demanding and repressive. Brutal forces were used to suppress the Tibetan resistance, first in Kham and Amdo, and finally in the whole of Tibet by March 1959 [...]. When this joyful occasion comes, the time when the Tibetans in Tibet and those in exile are re-united in a free Tibet, the present totalitarian system, dubbed centralised democracy, will have to give way to true democracy under which the people of all the three provinces of Tibet, namely U-Tsang, Kham and Amdo, can enjoy the freedom of thought, expression, and movement" (The Guidelines for Future Tibet's Polity, 1992). Comparing these two texts, what becomes noticeable is the fact that in the preamble to The Constitution of Tibet, the thread of dividing Tibetans into the ones inhabiting TAR and the ones remaining in exile, e.g., in India, Nepal or Bhutan and other parts of the world, was not clearly presented. What is also missing is a distinction between "exile" and "refuge". Therefore, what is not specified is whether in the case of Tibetans we deal with "exile" or "refuge" (cf. Roemer, 2008, p. 36) ${ }^{3}$. It may have stemmed from the fact that over thirty

2 Independence may refer both to 'the lack of dependence on' as well as to 'self-governing'. And what remains is the ambiguity: is it all about not depending on China or self-governing, that is, not being politically dependent on China; e.g., within the principle "one country, two systems" (chin. yiguóliăngzhi). The entities that function in such a way are, for instance, Macau and Hong Kong. On the way TAR functions in China as well as on its future prospects, cf. "One Country, Two Systems" Not Possible for Tibet (2006).

3 As suggested by Stephanie Roemer, and by the very name "Tibetan Government in Exile", the concept of exile is more descriptively adequate when it comes to doing justice to the situation of Tibetans (Roemer, 2008, p. 37). 
years of negotiations - mainly by Dalai Lama - with the government of China, no satisfactory results were achieved and due to repressions, the number of Tibetans leaving Tibet grew ${ }^{4}$. And hence, the visions cherished by Dalai Lama changed, the visions being related to some reconciliation between China and Tibet. It must be stressed that the said visions are not commonly accepted by Tibetans themselves. It is because the envisioned propositions are to involve offering to accept Chinese ownership of Tibet, while asking for a cessation of human rights abuses and a return to Tibetan control over internal affairs (Powers, 2007, p. 212). In the other scenario, as stressed by Karénina Kollmar-Paulenz, Dalai Lama offers to resign from the postulate of Tibet gaining independence and to stay within the sphere of influence of China in return for the preservation of Tibetan-Buddhist culture (2009, pp. 176-177). And this is, what is worth noticing, compatible with an excerpt from the introduction to a draft of the constitution, in which Dalai Lama mentions "the survival of a people with their own distinct history and culture" (The Guidelines for Future Tibet's Polity, 1992).

An important appendix in the introduction dating back to 1992 is the depiction of the changes in the attitudes of some part of Chinese towards the policies pursued by the Chinese government, especially after the Tiananmen Square protests of 1989 in Beijing. In this context, what is of interest are the following words: "Even the Chinese people themselves are opposed to the present Chinese system of governance and are demanding changes. Chinese dissidents in exile have come to realize and accept the reality that Tibet and China are two completely separate entities" (The Guidelines for Future Tibet's Polity). The quoted passage contains an important thread related to what belongs to Tibet's territory and what will be subject to a new political regime upon gaining independence. In Dalai Lama's opinion, future Tibet is to consist of three historical provinces, that is, of Kham (Tib. khams, Chin. Kāngbā), Amdo (Tib. a mdo, Chin. Ānduō), and Ü-Tsang (Tib. dbus-gtsang, Chin. Wèizàng) ${ }^{5}$. It is not only in the introduction that the three provinces are pointed to, for it is also in the main body of a draft of the constitution that we find numerous references to Tibet divided into provinces (cf. Constitution of Tibet, 1963 - especially Art. 68-74). This threat is grounded

4 Cf. World-Wide Demographic Survey of Tibetans in Exile Begins 12 April Thursday, 9 February 2009, 5:33 p.m.

5 The territory of contemporary Tibet, that is TAR, consists of providences Ü-Tsang, north-east part of the province Amdo and the western part of the province Kham (cf. Kapstein, 2006, pp. 5-8). The other parts of the provinces Amdo and Kham were taken over by the provinces of China, such as Sichuan (Chin. Sìchuān) and Qinghai (Chin. Qīnghăi). 
upon the fact that although Tibet after regaining independence will be endowed with a uniform political and national structure, the historical divisions are still in effect among Tibetans. It is to be understood that Tibet is not (was not) culturally uniform, which stems from the fact that it occupies a historically and geographically varied territory. It must be also admitted that it is neither linguistically uniform once we take heed of a few dialects of Tibetan (cf. Bareja-Starzyńska \& Mejor, 2002, pp. 26-28). That is why it is difficult to speak of coherence and an awareness of ethnic identity among the peoples identifying themselves as bod pa (cf. Kapstein, 2006, p. 2). It is also due to the Chinese invasion that Tibet does not constitute a uniform political entity (cf. Kollmar-Paulenz, 2009, p. 175). In the pre-modern era, ethnic and cultural Tibet was characterized by a large number of various social groups, a part of which was subject to the centralized political regime, whereas others were not subjugated to the central government (Kollmar-Paulenz, 2009, p. 14).

The issue of Tibetan national identity, which constitutes the second section, appears in the text of a draft of the constitution quite frequently, e.g., in the use of such phrases as: "the people of Tibet", "my people" (or "my People") ${ }^{6}$. What is telling is the fact that in the text, the coherence of national identity is mainly based on the confrontation with China. It is most conspicuous in the preamble, where we can read what follows: "Unfortunately, for me and my people, all our efforts were frustrated by the Chinese authorities who had established in Tibet the worst form of colonial regime. [...] Soon after my arrival in India I decided that a Draft Constitution should be prepared so as to give the people of Tibet a new hope and a new conception of how Tibet should be governed when she regained her freedom and independence. [...] It is my earnest hope that as soon as Tibet becomes once more free and independent, the system of government as laid down in this Constitution will be established for the benefit of my People" (Constitution of Tibet, 1963). On the other hand, in the introduction from 1992, this thread was much more concretized, namely: "[...] in terms of race, culture, language, dress and customs, Tibet is a distinct nation" (The Guidelines for Future Tibet's Polity, 1992). And thus, the process of creating Tibetan national identity is justified in a rather typical manner, that is, by revealing coherence and continuity of history especially when it pertains to political structure and culture. And more

6 In both formulations, what is noticeable is building the common identity of Tibetans as the people inhabiting the territory of Tibet and subject to a political power wielded by Dalai Lama. Whether we use the phrase "people" or "People" is of little importance. 
specifically: "Tibet has a recorded history of over 2,000 years, and according to archaeological findings, a civilization dating back to over 4,000 years. [...] Under Tibet's Kings and the Dalai Lamas, we had a political system that was firmly rooted in our spiritual values. As a result, peace and happiness prevailed in Tibet" (The Guidelines for Future Tibet's Polity, 1992). In the above quote, what is of greatest interest is the last sentence pointing not only to "the Golden Age" in Tibet's past, but also implicitly at the cause of the collapse thereof, which is attributable to Chinese invasion over Tibet and the former's incessant acculturation actions ${ }^{7}$. These purposes are to be served by numerous confrontational references to China, both explicitly and implicitly. Furthermore, these references are endowed with two other meanings. The first of these, directed at Tibetans, is depicting Tibet - regardless of whether what is meant is TAR or provinces - as being culturally distinct from China. The other is to convince the Western public opinion of the validity of the claim that Tibetans constitute a distinct nation. It is worthwhile to add that the issue of national identity does not occur in the scrutinized text as a postulate but as a fact and pointing to the undeniability and self-evidence thereof is supposed to strengthen the process of regaining independence and further political transformations of Tibet. That in turn can be regarded as typical of the process of shaping national identity.

\section{RELIGION AND POLITY IN FUTURE TIBET}

The two successive threads contained in a draft of the constitution pertain to the issues of religion and politics. They continue as well as supplement the two previously mentioned threads. First, we will scrutinize the relevant passages contained in a draft of the Tibetan constitution and being related to religion. These can be found in the content of the preamble, e.g.: "Thereafter, on the basis of these principles and in consultation with popular representatives, both lay and religious, this Constitution has been prepared in detail. This takes into consideration the doctrines enunciated by Lord Buddha, the spiritual and temporal heritage of Tibet and the ideas and ideals of the modern world. [...] We must all remember the teaching of Lord Buddha that truth and justice will prevail in the end" (Constitution of Tibet, 1963). The references to Buddhism also appear in

7 The actions undertaken by China contributed to shaping the national identity of Tibetans despite the differences between the two. 
the content of particular articles of the designed constitution. Namely, in Article 2 (Nature of Tibetan Polity) we can read what follows: "Tibet shall be a unitary democratic State founded upon the principles laid down by the Lord Buddha, and no change in the present Constitution shall be made except in accordance with the provisions hereinafter specified" (Constitution of Tibet, 1963). The case of Tibetan Buddhism, in the context of politics, is peculiar insofar as in its structure Dalai Lama performs an exceptionally sacred function combined with the position of a political leader of Tibetans. What is particularly characteristic is also the fact that the adherents of Gelug School regard him as an incarnation of bodhisattva of compassion, Avalokiteśvara (Skr. Avalokiteśvara, Tib. spyanrasgzigs). And additionally, he is considered a founder of the Tibetan state (Kollmar-Paulenz, 2009, p. 117). Second of all, introducing Tibetan Buddhism to a draft of the constitution, apart from regarding it as a basis of morality and of principles shaping social relations, stems from the fact that it is considered one of the major determinants of national identity of Tibetans.

Now let us turn to the fact that in the scrutinized text, politics, despite references made to religion and national-identity-related issues, constitutes a pivotal point of the whole project. The visions of future Tibet's polity as formulated by Dalai Lama in the sixties of the $20^{\text {th }}$ century can be described as hovering between a Western type of democracy and theocracy, that is, dmangsgtso'i ring lugs (Goldstein \& Narkyid, 1984, p. 106). This concept can be regarded as a rendition of the Greek etymon, and not as a loan translation of the word 'democracy', being operative in the West. And it is exactly in this spirit that it is defined by Dalai Lama. That is, he derives the concept from justice, equality and peace. It is particularly the last component that is of utmost importance; and what should be underlined, it essentially characterizes the Tibetan view since it is "democracy that has nonviolence and peace at its roots" (Dalai Lama, 1993).

Before we return to the thread of peace, let us have a closer look at the Tibetan vision of democracy, as specified in a draft of the constitution. On the conceptual level, democracy comprises the notions, as we remember, of justice and equality, both of which pertain mainly to economic and social issues. As stated in the preamble: "I also firmly believed that this could only be done through democratic institutions based on social and economic justice. [...] It is thus intended to secure for the people of Tibet a system of democracy based on justice and equality and ensure their cultural, religious and economic advancement" (Constitution of Tibet, 1963). On the other hand, in the introduction from 1992, democracy is characterized in more generic terms, such as, for example: "During 
those years, the world has changed dramatically and people throughout the world have begun to value democratic rights more than ever before. They have realised that democracy is the foundation for the free expression of human thoughts and potentials" (The Guidelines for Future Tibet's Polity, 1992). And in democracy, it is the concept of 'freedom' that starts playing a more vital role. The occurrence of the concept of freedom may be regarded as evidence of the changes in the relations between CTA and the Chinese government as well as the revaluation of priorities and of the ideas accompanying them. Namely: "When this joyful occasion comes, the time when the Tibetans in Tibet and those in exile are reunited in a free Tibet, the present totalitarian system, dubbed centralised democracy, will have to give way to true democracy under which the people of all the three provinces of Tibet, namely Ü-Tsang, Kham and Amdo" (The Guidelines for Future Tibet's Polity, 1992). In this case, Dalai Lama indirectly characterizes the Chinese system, dubbing it, by virtue of pointing to TAR, democratic centralism ${ }^{8}$, which is undeniably different from what is supposed to be introduced in Tibet. That is, as we read in Article 18 (Other Fundamental Freedoms): "Subject to any law imposing reasonable restrictions in the interests of the security of the State, public order, health or morality, all citizens shall be entitled to:

(a) freedom of speech and expression;

(b) assemble peaceably and without arms;

(c) form associations or unions;

(d) move freely throughout the territories of Tibet;

(e) the right to a passport to travel outside those territories;

(f) reside and settle in any part of Tibet;

(g) acquire, hold and dispose of property;

(h) practice any profession or carry on any occupation, trade or business" (Constitution of Tibet, 1963).

Properly understood democracy is to be based on freedom to express one's beliefs, and on freedom of possession as well as on freedom of association and practicing any profession or occupation - subsections (a), (c), (g), and (h) ${ }^{9}$. Doing

8 Such understanding is to be found in Constitution of the Peoples Republic of China (Zhōngh uárénmíngònghéguóxiànfă). Cf. Zhōnghuárénmíngònghéguóxiànfă (Art. 1 and Art. 3).

9 What may be mentioned at this point is that in Article 22 (Right to Hold Office) there is a complementation of the thread pertaining to repudiating gender discrimination and allowing women to hold public offices. Namely: "All Tibetans of either sex shall have the right to hold public offices, whether elective or otherwise, on conditions of equality in accordance with the requirements of law" (Constitution of Tibet, 1963). Cf. Art. 8-10 (Constitution of Tibet, 1963). 
away with the restrictions imposed on Tibetans and pertinent to moving freely to TAR and from a part of the provinces of the former Tibet to the territory of China - subsections (d) and (f). It should be also noticed that this article is connected with Tibet's gaining political independence as a state and with this newly-gained independence being recognized on the international arena - subsection $(e)^{10}$.

Lingering a little over Article 18, let us turn our attention to subsection (b) since it is related to the notion of "peace" and resigning from the use of violence and from Tibet's possessing any military power ${ }^{11}$. This thread can be regarded as a strictly Tibetan one and an exceptional one among other constitutions or documents performing the role thereof, for, except for the Japanese Constitution of 1947, in any other such documents the previously-stated postulate does not occur at all. In the content of a draft of the Tibetan constitution of 1992, there appears a supplement in the form of a principle upon which the resignation from the use of violence rests. It is "ahimsa" (Skt. ahimssa), being derived from Hinduism and then developed in Buddhism (cf. a draft of the Constitution, Art. 4). In case of the Tibetan project, what we deal with is references to the interpretation of peace by Mahatma Gandhi as well as to the images disseminated by Dalai Lama of a peaceful nature of Tibetans (cf. Dalai Lama, 1987, September 21). It should be added that the extension of concept of 'ahimsa' is much broader than 'resigning from the use of violence' because it is not limited to political issues but rather to any actions at all (cf. Elzenberg, 1991). We can witness it in the introduction to a draft of the Constitution of 1992: "My hope is that Tibet will then be a zone of peace, with environmental protection as its official policy" (The Guidelines of Future Tibet's Polity, 1992). And in Article 4 thereof: "Future Tibet will be a peace-loving nation, adhering to the principle of Ahimsa. It will have a democratic system of government committed to preserving a clean, healthy and beautiful environment. Tibet will be a completely demilitarised nation" (Principal Features of the Constitution, 1992). This postulate is reproduced as a sort

10 It is worth recalling that the issue of recognizing the aspiration of Tibet, and especially of TAR, to be independent of China is neither obvious nor commonly shared. E.g., at the beginning of March 2017, a group of Tibetan soccer players was not allowed to enter USA because the latter's government regard Tibetans inhabiting TAR as citizens of China (Fuchs, 2017).

11 Cf. Art. 6 (Renunciation of War): "In accordance with its traditions, Tibet renounces war as an instrument of offensive policy and force shall not be used against the liberty of other peoples and as a means of resolving international controversies and will hereby adhere to the principles of the Charter of the United Nations" (Constitution of Tibet, 1963). 
of "political myth" about Tibet as a kind of Shangri $\mathrm{La}^{12}$, as a land of happiness and peace; and about Tibetans as the people not resorting to violence in settling disputes (Kollmar-Paulenz, 2009, pp. 175-176).

An important thread contained in a draft of the Tibetan constitution and related to the process of democratisation of future Tibet's polity is an issue of elections to Kashag, that is, to the Tibetan parliament, and of introducing a tripartite separation of powers. With reference to the first thread, the following article applies (Art. 70, Constitution of Regional Councils):

(1) There shall be a Regional Council in each region consisting of such number of members as may be determined by His Holiness the Dalai Lama in consultation with the National Assembly.

(2) The members of the Regional Council shall be elected by persons qualified to vote for the election of members of the National Assembly.

(3) The election shall take place at such times as the Governor shall direct in consultation with the Kashag.

(4) Each Regional Council shall continue for three years from the date of its first meeting and shall not be subject to dissolution save by affluxion of time" (Constitution of Tibet, 1963).

It is to be underlined that in a draft of the Tibetan constitution, the threads pertinent to elections were reduced to the principles specifying how Kashag is supposed to function. What is missing therein, and what appears to be interesting in the context of other constitutions of democratic regime, is an indication of election law connected with party system. If we have a look at a draft of 1992, apart from the resemblances of its content, we can witness a clear evolution of this thread because the said constitution includes the remarks pertaining to political parties. Namely, we can read in Article 13 (Executive Power) what follows: "(b) the executive power of the Government, under the parliamentary system, will rest with the Prime Minister and the Council of Ministers formed by the Prime Minister. The Prime Minister must be from a party or any other group constituting the majority of members present in the House of People. Failing this, the entire body of members of the House of People will elect the Prime Minister" (Principal Features of the Constitution, 1992).

12 A fictional utopian place located in Himalayas, invented by James Hilton in his novel Lost Horizon (1933). 
A similar statement may be found in the introduction, in which Dalai Lama points out the need for a complex party system in future Tibet which will be represented in Kashag.

In the professional literature, we can encounter the opinions that from the mid-1960s to 1990s, there was a gradual evolution of a government in Dharamsala that was very similar to what the west understands as democracy (Boyd, 2005, p. 25). We got convinced of the soundness of this remark before, when we were indicating the features of Tibetan understanding of democracy. What is more, the proposition by Dalai Lama approximates a polyarchic model of democracy (cf. Dahl). This can be also evidenced by the postulate of introducing in future Tibet the separation of powers, that is, separating the executive from the judiciary power. However, while analysing the content of a draft, we readily notice that the above-mentioned separation was not developed therein and it remains at the level of a very general proposition. What is more, the suggestions contained therein, in spite of their pointing out the need to democratize the Tibetan regime, hint at typically theocratic solutions. Let us take a closer look at particular articles pertaining to a tripartite separation of powers. We can read in Article 29 (Executive Power) what follows: "The executive power of the State shall be vested in His Holiness the Dalai Lama on his attaining the age of eighteen and shall be exercised by him either directly or through officers subordinate to him in accordance with the provisions of this Constitution" (Constitution of Tibet, 1963).

In the case of legislative power, in Art. 38 (Legislative Power): "All Legislative power shall vest in the National Assembly subject to the assent of His Holiness the Dalai Lama" (Constitution of Tibet, 1963). And as well as judiciary power, in Art. 62 (Constitution of the Supreme Court):

"(1) There shall be a Supreme Court consisting of a Chief Justice and, until the National Assembly by law prescribes a larger number, of not more than three other Judges.

(2) Every Judge of the Supreme Court shall be appointed by His Holiness the Dalai Lama and shall hold office during the pleasure of His Holiness the Dalai Lama unless sooner removed by two-thirds majority of the National Assembly and assented to by His Holiness the Dalai Lama. Provided that in the case of appointment of a Judge other than the Chief Justice, the Chief Justice shall always be consulted" (Constitution of Tibet, 1963).

What is telling about the above-cited articles is that the legislative, executive and judiciary powers are subordinated to Dalai Lama, who is referred to, in Art. 29(2), as 'the Head of the State', and in Art. 77(3), as 'the Spiritual Head of the 
State'. Assigning such a position to Dalai Lama, coupled with political functions, is typical of theocratic states, in which 'the Head of the State' is a priest. It is worthwhile to add that the provisions, in the context of the project of 1992, were amended. Namely: "Personally, I have made up my mind that I will not play any role in the future government of Tibet, let alone seek the Dalai Lama's traditional political position in the government" (The Guidelines for Future Tibet's Polity, 1992).

On the other hand, in a draft of the constitution; more specifically, in the articles related to the legislative, executive and judiciary powers, Dalai Lama does not function as 'the Head of the State' since his functions are to be taken over by a President (cf. Principal Features of the Constitution - especially Art. 12-14).

\section{CONCLUSION}

Being interested in policies and laws of future Tibet stems not only from the fact that Tibet, when it comes to international relations, constitutes an important research problem. The said interest in those issues also derives from noticing the idiosyncrasies of a political regime operative till the times of the Chinese invasion. It is also a legal regime that appears to be an extraordinary and integral part of culture, upon which external legal regimes have not exerted any significant influence (French, 2012, p. 439). And it is for this reason that we should investigate these areas of Tibetan culture that have been so far overlooked in Tibetological and political-study-related studies. What is more, in this case we deal with an interesting instance of a society based on other cultural patterns, which, when modernized, are combined with Western solutions and ideas.

The predicament in which Tibetans were caught from the fifties of the $20^{\text {th }}$ century made their so-far methods of pursuing policies get modified. Apart from the negative influence exerted by the process of acculturation pursued by the Chinese government, in TAR as well as in CTA there was commenced a process of shaping the national identity of Tibetans. As noted by John Powers: "It is important to note that Tibetans in exile have not simply sought to preserve their traditions; they are also formulating new ones and planning for the return to their homeland that they fervently desire. Most Tibetans firmly believe that they will be able to return someday to a free Tibet, and their leaders are anticipating this with plans to revamp the society. An important step in this direction was the drafting in 1963 of a constitution for free Tibet, which instituted democratic 
elections and abolished many of the archaic institutions of the old order" (2007, p. 205).

What was underlined in the above-quoted passage was an aspect of the national identity of Tibetans which oftentimes appears in Tibetological literature. However, political-regime- and legal-regime-related issues are often not subject to scholarly scrutiny. It may stem from the fact that the issues pertaining to inter-state relations of CTA and TAR, if we can say so, dominated the nowadays discourse both in the studies prepared by Tibetans and by Western scholars and journalists. That is why analysing a draft of the constitution of future Tibet seems not only interesting but also needed.

A draft of the constitution - as opposed to what Powers claims in the abovequoted passage - was not a ready text but was rather subject to modifications. It counts as some evidence of the possibility that the nature of the relations between CTA and China changes; and Dalai Lama's awareness of the issues related to politics is characterized by some dynamism. What confirms that is the provision introduced to a draft of the constitution that claims the diminishment of Dalai Lama's power (Powers, 2007, p. 205) - but only in the version of 1992. Introducing this provision may be regarded as a challenge to future Tibet's government. On the one hand, the government will have to seek for new ideas to legitimize its political regime. And on the other, it will undergo the process of modernization which will require to redefine an old political and social order. It is also worthwhile to add that observing a dynamic evolution of foreign policy and internal policy of CTA, we can attempt to understand the peculiarities of Tibetan's view of politics. And also, we can attempt to specify how the future of a relatively young political structure might be shaped under rather specific circumstances, that is, the lack of statehood on the part of CTA. That is why describing and analysing these threads may considerably contribute to extending our knowledge on contemporary Tibet.

\section{ReFERENCES:}

Bareja-Starzyńska, A., \& Mejor, M. (2002). Klasyczny język tybetański. Warszawa: Wydawnictwo Dialog.

Boyd, H.R. (2005). The Future of Tibet: The Government-in-Exile Meets the Challenge of Democratization. New York: Peter Lang Publishing.

Constitution of Tibet (1963). Retrieved from: http://www.tibetjustice.org/materials/ tibet/tibet2.html. 
Dalai Lama (1987). Address to the U.S. Congressional Human Right's Caucus. Retrieved from: https://www.dalailama.com/messages/tibet/five-point-peace-plan.

Dalai Lama (1993). Buddhism and Democracy. Retrieved from: https://www.dalailama. $\mathrm{com} / \mathrm{messages} /$ buddhism/buddhism-and-democracy.

Elzenberg, H. (1991). Ahimsa i pacyfizm. Rzecz o gandyzmie. In: H. Elzenberg, Z filozofii kultury (pp. 170-176). Kraków: Znak.

French, R.R. (2012). Tybetańska literatura prawna. Kodeksy prawne Ganden-Phodrang (dGa'ldan pho brang). In: J.I. Cabezón, R.R. Jackson (eds.), Klasyczna literatura tybetańska (p. 439). Warszawa: Wydawnictwo Dialog.

Fuchs, Ch. (2017). Tibetan Women's Soccer Team Respond After Being Denied U.S. Visas for Tournament. Retrieved from: https://www.nbcnews.com/news/asian-america/ denied-visas-u-s-tibet-women-s-soccer-team-hold-n728626.

Goldstein, M.C., \& Narkyid, N. (1984). English-Tibetan Dictionary of Modern Tibetan. Berkeley-Los Angeles-London: University of California Press.

Kapstein, M.T. (2006). The Tibetans. Malden: Blackwell Publishing.

Kollmar-Paulenz, K. (2009). Tybet. Zarys historii. Warszawa: Wydawnictwo Dialog.

Mullin, G.H. (2008). Czternastu dalajlamów. Spadkobiercy oświeconej mądrości. Warszawa: Jacek Santorski \& Co Agencja Wydawnicza.

“One Country, Two Systems” Not Possible for Tibet (2006). Retrieved from: http://www. china-embassy.org/eng/zt/zgxz/t265334.htm.

Powers, J. (2007). Introduction to Tibetan Buddhism. Ithaca: Snow Lion Publication.

Principal Features of the Constitution (1992). Zarys konstytucji. Retrieved from: http:// www.hfhrpol.waw.pl/Tybet/drukuj.php?raport_id=114.

Roemer, S. (2008). The Tibetan Government-in-Exile: Politics at Large. London-New York: Routledge.

The Guidelines for Future Tibet's Polity (1992). Polityka przyszłego Tybetu. Retrieved from: http://www.hfhrpol.waw.pl/Tybet/drukuj.php?raport_id=114.

van Walt van Praag, M.C. (1988). The Legal Status of Tibet. Cultural Survival Quarterly Magazine, 12(1). Retrieved from: https://www.culturalsurvival.org/publications/ cultural-survival-quarterly/legal-status-tibet.

World-Wide Demographic Survey of Tibetans in Exile Begins 12 April Thursday, 9 February 2009, 5:33 p.m. Retrieved from: http://tibet.net/2009/04/world-widedemographic-survey-of-tibetans-in-exile-begins-12-april/.

Zhōnghuá rénmín gònghéguó xiànfă. Retrieved from: http://www.gov.cn/gongbao/ content/2004/content_62714.htm. 